\title{
Adhesion to Mineral Surfaces by Cells of Leptospirillum, Acidithiobacillus and Sulfobacillus from Armenian Sulfide Ores
}

\author{
Arevik Vardanyan ${ }^{1} \mathbb{D}$, Narine Vardanyan ${ }^{1}$, Anna Khachatryan ${ }^{1}$, Ruiyong Zhang ${ }^{2,3, *}$ \\ and Wolfgang Sand $2,4,5$ \\ 1 Institute of Microbiology of SPC “Armbiotechnology” of NAS of Armenia, Gyurjyan 14, \\ Yerevan 0056, Armenia; avivardan@gmail.com (A.V.); nvard@sci.am (N.V.); \\ anna.khachatryan.92@bk.ru (A.K.) \\ 2 Aquatic Biotechnology, Biofilm Centre, University of Duisburg-Essen, Universitätsstraße 5, \\ 45141 Essen, Germany; wolfgang.sand@uni-due.de \\ 3 Federal Institute for Geosciences and Natural Resources (BGR), Stilleweg 2, 30655 Hannover, Germany \\ 4 Institute of Bioscience, Environmental Microbiology, TU Bergakademie Freiberg, Leipziger Straße 29, \\ 09599 Freiberg, Germany \\ 5 College of Environmental Science and Engineering, Donghua University, Shanghai 201600, China \\ * Correspondence: ruiyong.zhang@uni-due.de or ruiyong.zhang@bgr.de
}

Received: 6 December 2018; Accepted: 20 January 2019; Published: 24 January 2019

\begin{abstract}
Bioleaching of metal sulfides is an interfacial process where adhesion and subsequent biofilm formation are considered to be crucial for this process. In this study, adhesion and biofilm formation by several acidophiles (Acidithiobacillus, Leptospirillum and Sulfobacillus) isolated from different biotopes with sulfide ores in Armenia were studied. Results showed that: (1) these bacteria adhere to pyrite surfaces to various extents. A correlation between pyrite biooxidation and adhesion of S. thermosulfidooxidans 6, L. ferriphilum CC, L. ferrooxidans ZC on pyrite surfaces is shown. It is supposed that bioleaching of pyrite by $S$. thermosulfidooxidans 6, L. ferriphilum CC, L. ferrooxidans ZC occurs by means of indirect leaching: by ferric iron of bacterial origin; (2) cells of At. ferrooxidans 61, L. ferrooxidans ZC and St. thermosulfidooxidans 6 form a monolayer biofilm on pyrite surfaces. The coverage of pyrite surfaces varies among these species. The order of the biofilm coverage is: L. ferrooxidans $\mathrm{ZC} \geq$ At. ferrooxidans $61>$ St. thermosulfidooxidans 6; (3) the extracellular polymeric substances (EPS) analysis indicates that the tested strains produce EPS, if grown either on soluble ferrous iron or solid pyrite. EPS are mainly composed of proteins and carbohydrates. Cells excrete higher amounts of capsular EPS than of colloidal EPS. In addition, cells grown on pyrite produce more EPS than ones grown on ferrous iron.
\end{abstract}

Keywords: adhesion; biofilm; extracellular polymeric substances (EPS); atomic force microscopy (AFM); epifluorescence microscopy (EFM)

\section{Introduction}

Biomining is the term used to describe the technology that uses microbes to achieve metal extraction from minerals or waste materials. Biomining of gold or other precious metals normally involves a pre-treatment process using iron-oxidizing and/or sulfur-oxidizing bacteria or archaea prior to cyanide extraction [1]. This process is known as biooxidation. Compared to the traditional mineral processing technology like ore smelting/toasting, biomining is more attractive regarding to its lower energy costs and also is more environmentally friendly. In addition, due to the autotrophic lifestyle of most bioleaching microbes, bioleaching involves less carbon footprints $\left(\mathrm{CO}_{2}\right.$ fixation by 
autotrophs) compared to smelting operations ( $\mathrm{CO}_{2}$ emission) [2]. Biomining is an increasingly applied biotechnological procedure for processing of ores in the mining industry (biohydrometallurgy) [3]. This technology converts an insoluble valuable metal sulfide into a soluble form by means of microorganisms [4]. Iron-oxidizing bacteria destroy the lattice of the sulfide minerals to make the gold available for further extraction by cyanidation [1]. Studies have shown that Leptospirillum sp. (mainly Leptospirillum ferriphilum) are the dominating iron-oxidizing bacteria in gold-bearing arsenopyrite (FeAsS) and pyrite $\left(\mathrm{FeS}_{2}\right)$ in biooxidation reactors functioning at or over $40{ }^{\circ} \mathrm{C}$ [5-8]. A high $\mathrm{Fe}^{3+} / \mathrm{Fe}^{2+}$ ratio, elevated temperatures $\left(40{ }^{\circ} \mathrm{C}\right)$, as well as extremely low $\mathrm{pH}$ values $(\mathrm{pH} 1.0)$ are the most favorable conditions for the growth of the bacteria of the genus Leptospirillum $[7,9]$. At present, this genus includes: L. ferrooxidans (Group I), L. ferriphilum, "L. rubarum" (Group II), and "L. ferrodiazotrophum" (Group III). Bacteria of the genus Leptospirillum are Gram-negative, acidophilic, motile vibrios, which fix carbon dioxide using the energy of Fe (II) ion oxidation [5,10-13].

Recently, scientists emphasized the importance of bacteria of the genus Leptospirillum and their mixed cultures with other bacteria for biooxidation and bioleaching processes at temperatures above $40{ }^{\circ} \mathrm{C}[12,14-16]$.

The bacterial leaching of sulfide minerals is primarily an indirect process involving the reduction of ferric ions (Fe (III)):

$$
\mathrm{MS}+2 \mathrm{Fe}^{3+} \rightarrow \mathrm{M}^{2+}+\mathrm{S}^{0}+2 \mathrm{Fe}^{2+}
$$

According to the indirect "contact" mechanism the oxidation of minerals is caused by Fe (III) ions complexed in extracellular polymeric substances (EPS). Thus, adhesion and biofilm formation by iron-oxidizing bacteria is essential for an efficient biooxidation or bioleaching of sulfide minerals [16-20]. The EPS mediate cell attachment to minerals as well as electrochemical reactions taking place at mineral surfaces during bioleaching processes $[16,19,21]$. However, there are few data concerning the adhesion of leaching bacteria like Leptospirillum spp. on pyrite, as well as evidence for a relation between their adhesion and intensity of iron-oxidizing activities in mineral bioleaching processes [22,23].

Most bacteria and archaea use the biofilm lifestyle in natural and artificial systems. A biofilm is considered to be a dynamic structure of a microbial population enclosed in a matrix [24-26]. The biofilm matrix is a complex mixture of EPS comprised of polysaccharides, proteins, lipids, and nucleic acids plus detritus [27]. Filling the intercellular space between cells, the EPS generate the structure of the biofilm matrix. The primary function of the EPS is to mediate the attachment of cells onto a substrate as well as to protect the cells from unfavorable environmental influences [28]. In addition, EPS have the function of aggregation formation and stabilization of biofilms. Depending on the mechanisms required for removal of EPS and their association with the cells, EPS can be subdivided into capsular (tightly bound) EPS and colloidal (loosely bound) EPS [29,30].

Biofilm formation is a prerequisite for efficient bioleaching of minerals [16,21]. Thus, in order to improve bioleaching and better control of biocorrosion the study of EPS structure and function of EPS from bioleaching bacteria is of crucial importance [31].

Despite the environmental and economic importance of these bacterial activities, very little fundamental information concerning chemical and biochemical events at the mineral surface during dissolution due to the presence of bioleaching microorganisms is available. The aim of the work is to study the main biological properties of iron-oxidizing and sulfur-oxidizing bacteria isolated from sulfide ores in Armenia. These include their ability to adhere on pyrite and to form biofilm and EPS during the bioleaching process.

\section{Materials and Methods}

\subsection{Bacterial Strains and Growth Conditions}

The iron-oxidizing strains Leptospirillum ferrooxidans ZC, L. ferriphilum CC, and the iron and sulfur-oxidizing bacteria Acidithiobacillus ferrooxidans 61, At. ferrooxidans 13Zn, Sulfobacillus 
thermosulfidooxidans 6 were isolated from several natural biotopes with sulfide ores in Armenia (Figure S1). The pure cultures of these bacteria were obtained by streak plate method [32]. The bacterial characteristics are shown in Table 1. Iron-oxidizing bacteria were cultivated in Mackintosh medium [33] containing $4.9 \mathrm{~g} / \mathrm{L}$ ferrous iron at optimal temperature. In case of $\mathrm{Sb}$. thermosulfidooxidans $0.02 \%$ yeast extract was added. Cells were harvested at $8000 \mathrm{rpm}$ for $10 \mathrm{~min}$ at $20{ }^{\circ} \mathrm{C}$, washed once and resuspended in $10 \mathrm{~mL}$ Mackintosh medium without ferrous iron for attachment and bioleaching tests.

Table 1. Description of the bioleaching strains *.

\begin{tabular}{|c|c|c|c|c|}
\hline Isolates & Original Sites & $\begin{array}{c}\text { Energy } \\
\text { Substrates }\end{array}$ & $\begin{array}{l}\text { Optimum } \\
\text { pH }\end{array}$ & $\begin{array}{l}\text { Optimum } \\
\mathrm{T}\left({ }^{\circ} \mathrm{C}\right)\end{array}$ \\
\hline At. ferrooxidans 61 & $\begin{array}{l}\text { Tandzut (Polymetallic, } \\
\text { gold containing) ore acid drainage } \\
\text { water, Lori Province, Armenia }\end{array}$ & $\begin{array}{l}\mathrm{Fe}^{2+}, \mathrm{S}^{0} \\
\text { metal sulfides }\end{array}$ & $1.8-2.0$ & 30 \\
\hline At. ferrooxidans $13 \mathrm{Zn}$ & $\begin{array}{l}\text { An industrial leaching pulp of } \\
\text { zinc concentrate, Armenia }\end{array}$ & $\begin{array}{c}\mathrm{Fe}^{2+}, \mathrm{S}^{0} \\
\text { metal sulfides }\end{array}$ & $1.8-2.0$ & $30-35$ \\
\hline L. ferrooxidans ZC & $\begin{array}{l}\text { An industrial leaching pulp of } \\
\text { zinc concentrate, Armenia }\end{array}$ & $\begin{array}{c}\mathrm{Fe}^{2+} \\
\text { metal sulfides }\end{array}$ & $1.8-2.0$ & $30-37$ \\
\hline L. ferriphilum CC & $\begin{array}{l}\text { An industrial leaching pulp of } \\
\text { copper concentrate, Armenia }\end{array}$ & $\begin{array}{l}\mathrm{Fe}^{2+}, \\
\text { metal sulfides }\end{array}$ & $1.8-2.0$ & 37 \\
\hline Sb. thermosulfidooxidans 6 & $\begin{array}{c}\text { Drmbon ore dumps (gold, copper) } \\
\text { in Martakert Province } \\
\text { (Nagorno-Karabakh), Armenia }\end{array}$ & $\begin{array}{c}\mathrm{Fe}^{2+}, \mathrm{S}^{0} \\
\text { metal sulfides }\end{array}$ & $1.7-1.8$ & $37-50$ \\
\hline
\end{tabular}

\subsection{Bacterial Adhesion Test}

Cells of At. ferrooxidans 61, At. ferrooxidans 13Zn, L. ferrooxidans ZC, L. ferriphilum CC and $S b$. thermosulfidooxidans 6 were tested for bacterial adhesion onto the surface of pyrite grains for $0 \mathrm{~min}, 30 \mathrm{~min}, 60 \mathrm{~min}$, and $120 \mathrm{~min}$. The number of planktonic cells was determined by direct counting under the microscope by means of a Thoma chamber or by the most probable number (MPN).

For enumeration of iron-oxidizing bacteria, the method of ten-fold serial dilution was used. Dilutions $\left(10^{-1}-10^{-9}\right)$ of samples were used for inoculation. Cultures were incubated in Mackintosh medium. After 7-10 days of incubation the growth of bacteria was checked by light microscope (Leica, Wetzlar, Germany). Obtained results of bacterial cells were calculated using McCrady's table [34].

The number of adhered cells was determined from the difference between the initial titre of bacterial cells and the cells observed in the liquid phase. The adhesion was determined as the percentage of adhered cells versus the initial cell number.

\subsection{Bioleaching of Pyrite}

For pyrite bioleaching experiments, strains were grown in Mackintosh medium containing $\mathrm{Fe}^{2+}$ as an energy source. In the logarithmic growth phase, the cells were collected by centrifugation at $6000 \mathrm{rpm}$ for $10 \mathrm{~min}$. The collected biomass was washed with acidified Mackintosh medium (pH 1.8) and resuspended in the same medium. Pyrite $\left(\sim 95 \% \mathrm{FeS}_{2}\right)$ from the Shamlugh ore deposit in Armenia ground to $43-63 \mu \mathrm{m}$ was used for leaching experiments. Leaching experiments were carried out in $250 \mathrm{~mL}$ conical flasks. $50 \mathrm{~mL}$ Mackintosh medium without $\mathrm{Fe}^{2+}$, adjusted to $\mathrm{pH} 2.0$ by $\mathrm{H}_{2} \mathrm{SO}_{4}$ and a bacterial suspension with $5 \mathrm{~g}$ pyrite grains were added to the flasks. The initial cell number was $1-2 \times 10^{8}$ cells $/ \mathrm{mL}$. The bioleaching experiments were carried out at $37^{\circ} \mathrm{C}$ with shaking $(180 \mathrm{rpm})$. The intensity of pyrite oxidation was estimated by the quantity of the dissolved $\mathrm{Fe}^{3+}$ and $\mathrm{Fe}^{2+}$ ions in the medium. Sampling was performed over a period of $25-30$ days. $\mathrm{Fe}^{2+}$ and $\mathrm{Fe}^{3+}$ ions were determined by complexometric titration by using ethylenediaminetetraacetic acid (EDTA). Total iron ions were determined by atomic-absorption spectrophotometry AAS 1N (Carl Zeiss, Jena, Germany) using an air-propane-butane flame. 


\subsection{Pyrite Coupon Preparation}

Pyrite coupons were cut from pyrite cubes from Navajun (Spain) with a diamond saw. These coupons were cleaned and sterilized according to a previous report [35]. Biofilm formation experiments were performed with $5 \times 10^{8}$ cells $/ \mathrm{mL}$. Experiments were carried out in 100-mL Erlenmeyer flasks containing $50 \mathrm{~mL}$ Mackintosh medium ( $\mathrm{pH} 1.8$ ) at 30, 37 and $45^{\circ} \mathrm{C}$ with shaking at $130 \mathrm{rpm}$.

\subsection{Visualization of Attached Cells on Pyrite Coupons}

Pyrite slices were rinsed with sterile Mackintosh medium and deionized water. Cells attached to pyrite coupons and their EPS were stained by Syto 9 (Invitrogen) and fluorescently labeled with Con A according to a previous report [36]. Stained samples were dried at room temperature and visualized by epifluorescence microscopy (EFM) (Zeiss, Jena, Germany) combined with atomic force microscopy (AFM) (BioMaterial ${ }^{\mathrm{TM}}$ Workstation, JPK Instruments, Berlin, Germany) for the investigation of cell morphology and distribution on the surfaces of pyrite coupons. At least three spots of each sample were documented.

\subsection{Image Processing}

Digital image analysis and a rough calculation of surface coverage were done by using the Axiovision LE 4.8 software (Zeiss, Jena, Germany) and an extended version of the software ImageJ (v1.52g, National Institutes of Health, Bethesda, USA) [37], respectively. AFM files were processed using JPKSPM_Data_Processing_v5.0.81 (JPK Instruments, Berlin, Germany).

\subsection{EPS Extraction}

EPS extraction strains were grown in $10 \mathrm{~L}$ Mackintosh medium at 30,37 and $45^{\circ} \mathrm{C}$ with shaking at $130 \mathrm{rpm}$. In the stationary growth phase, cells were harvested by centrifugation for $10 \mathrm{~min}$ at $10,000 \mathrm{rpm}$ at $4{ }^{\circ} \mathrm{C}$. The colloidal and capsular EPS were obtained according to a previous report [29].

Extraction of EPS of pyrite-grown cells: Bacterial strains were grown on pyrite in Mackintosh medium. To obtain sessile cells, $10 \mathrm{~g}$ of pyrite grains were washed with basal salt solution. Detachment of sessile cells from pyrite grains was performed mechanically by vortexing in $20 \mathrm{~mL}$ of basal salt solution at maximum speed for $5 \mathrm{~min}$ [38]. Solutions were used for analyses of the EPS composition of the strains. The content of carbohydrates, protein, and uronic acids were determined in $1 \mathrm{~mL}$ aliquots.

\subsection{Determination of the Chemical Composition of the EPS}

Carbohydrates were determined by the Dubois method [39] using glucose as standard and measured at $490 \mathrm{~nm}$. The protein content was determined by the Bradford method using bovine serum albumin (BSA) as standard and measured at $595 \mathrm{~nm}$ [40]. The presence of uronic acids was determined by the Blumenkrantz and Asboe-Hansen method [41]. Cell lysis was evaluated by determination of 3-Deoxy-D-manno-oct-2-ulosonic acid (KDO) [42]. The concentration of carbohydrates, protein, and uronic acids were determined in $\mu \mathrm{g}$ per $\mathrm{mL}$ of culture medium.

\subsection{Statistical Analysis}

Experiments were done in triplicate; the results are given in mean values. Standard deviations (SD) generally amount to $\leq 10 \%$ for adhesion, $\leq 15 \%$ for EPS analysis, and $\leq 6 \%$ for surface coverage analysis.

\section{Results and Discussion}

\subsection{Adhesion of Newly Isolated Strains and Bioleaching of Pyrite}

The planktonic cells of L. ferriphilum CC grown on pyrite culture decreased by $1-2 \times 10^{8}$ cells $/ \mathrm{mL}$ to $1 \times 10^{5}$ cells $/ \mathrm{mL}$ and to $1 \times 10^{4}$ cells $/ \mathrm{mL}$, in 30 and $120 \mathrm{~min}$ (respectively) after inoculation. 
The adhesion was 99\% and 100\% respectively (Table 2). The initial adhesion of L. ferriphilum CC on pyrite mostly occurred within the first $30 \mathrm{~min}$, whereas for cells of Sb. thermosulfidooxidans 6 and L. ferrooxidans ZC the adhesion reached only $88 \%$ and $93 \%$ after $120 \mathrm{~min}$ (Table 2).

Table 2. Adhesion * of four leaching isolates to pyrite determined by direct counting or most probable number (MPN).

\begin{tabular}{ccccc}
\hline \multirow{2}{*}{ Duration } & \multicolumn{3}{c}{ Strains } \\
\cline { 2 - 5 } & L. ferrooxidans ZC & Sb.thermosulfidooxidans $\mathbf{6}$ & At. ferrooxidans $\mathbf{6 1}$ & L.ferriphilum CC \\
\hline 0 & 0 & 0 & 0 & 0 \\
$30 \mathrm{~min}$ & 50 & 50 & 62 & 99 \\
$60 \mathrm{~min}$ & 65 & 61 & 83 & 99 \\
$120 \mathrm{~min}$ & 93 & 88 & 93 & 100 \\
\hline
\end{tabular}

* Values given in $\%$ of initial inoculum.

Bioleaching of pyrite from Shamlugh ore (Armenia) was studied with L. ferriphilum CC, Sb. thermosulfidooxidans 6, L. ferrooxidans ZC. The concentrations of leached iron over time are shown in Figure 1. The amount of total iron extracted from pyrite by L. ferriphilum CC was higher than that of L. ferrooxidans ZC or Sb. thermosulfidooxidans 6.

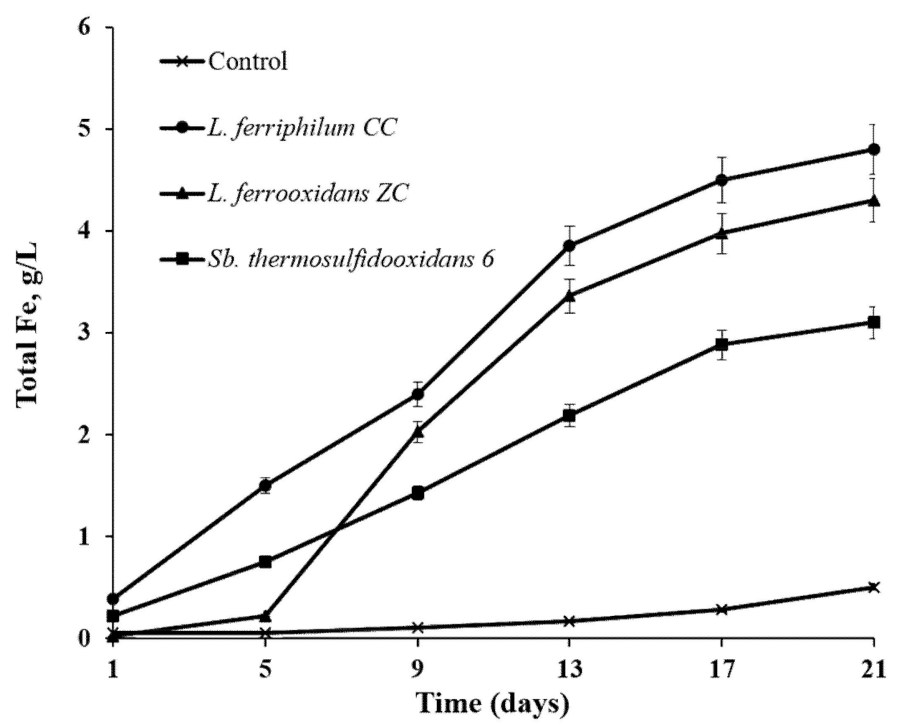

Figure 1. Bioleaching of pyrite $\left(\mathrm{FeS}_{2}\right)$ measured by the release of iron ions, in assays without bacteria (Control), with L. ferriphilum CC, L. ferrooxidans $\mathrm{ZC}$, and Sb. thermosulfidooxidans $6\left(\mathrm{FeS}_{2}-5 \%, \mathrm{pH}=2.0\right.$, $\mathrm{T}=37^{\circ} \mathrm{C}$, shaking-180 rpm).

The results of pyrite bioleaching (Figure 1) together with the data on adhesion of cells seem to indicate that the extracted iron and amount of adhered cells are positively related. This agrees with previous findings [22,32].

It has been shown that up to $80-90 \%$ of a certain inoculum can attach to mineral surfaces from solution within $24 \mathrm{~h}$ [22,43-45]. In addition, the initial attachment strongly depends on the species as well as their pre-cultivation conditions. In general, Leptospirillum spp. show higher attachment to pyrite than iron-oxidizing Acidithiobacillus spp., and among the latter ones, ferrous iron-grown or pyrite-grown cells show higher attachment to pyrite than sulfur-grown cells due to a chemically, considerably different EPS [45]. Nevertheless, some cells always remain in the planktonic state, even though the surface area for attachment is not the limiting factor [46,47]. For example, if cells of At. ferrooxidans ATCC $23270^{\mathrm{T}}$ or At. ferrivorans are incubated with pyrite for $24 \mathrm{~h}$, about $50 \%$ of the cells attach under the experimental conditions [48]. In the current studies, L. ferriphilum CC showed a higher level of adhesion and pyrite oxidation than Sb. thermosulfidooxidans 6 and L. ferrooxidans 
ZC. The quantity of cell occurred in the following order: L. ferriphilum CC $>$ L. ferrooxidans ZC $>$ At. ferrooxidans 61. Sb. thermosulfidooxidans 6 showed the lowest adhesion to pyrite.

\subsection{Biofilm Formation}

The visualization of biofilm formation by cells of At. ferrooxidans 61, L. ferrooxidans ZC and $S b$. thermosulfidooxidans 6 on pyrite coupons is presented in Figures 2-4, respectively. In general, the three strains form a monolayer biofilm on pyrite. Also, the biofilms are highly heterogeneous, as has been reported for many bioleaching microorganisms [23,49,50]. At. ferrooxidans 61 and $\mathrm{Sb}$. thermosulfidooxidans 6 colonize pyrite mainly in the form of individual cells. In some cases, At. ferrooxidans 61 formed chains of cells with up to $4.5 \mu \mathrm{m}$ in length. Cells of Sb. thermosulfidooxidans 6 appears as short rods with a size of $0.5-0.8 \mu \mathrm{m} \times 1.0-1.7 \mu \mathrm{m}$. In case of $L$. ferrooxidans ZC, individual cells were spiral and large cell clusters with diameters of $25 \mu \mathrm{m}$ occurred (Figure 3). The formation of aggregates indicates that $L$. ferrooxidans ZC may possess the ability to produce large amounts of EPS. This is in agreement with the finding that Con A signals from EPS of L. ferrooxidans ZC were considerably denser than the ones from the EPS of cells of At. ferrooxidans 61 or Sb. thermosulfidooxidans 6 .

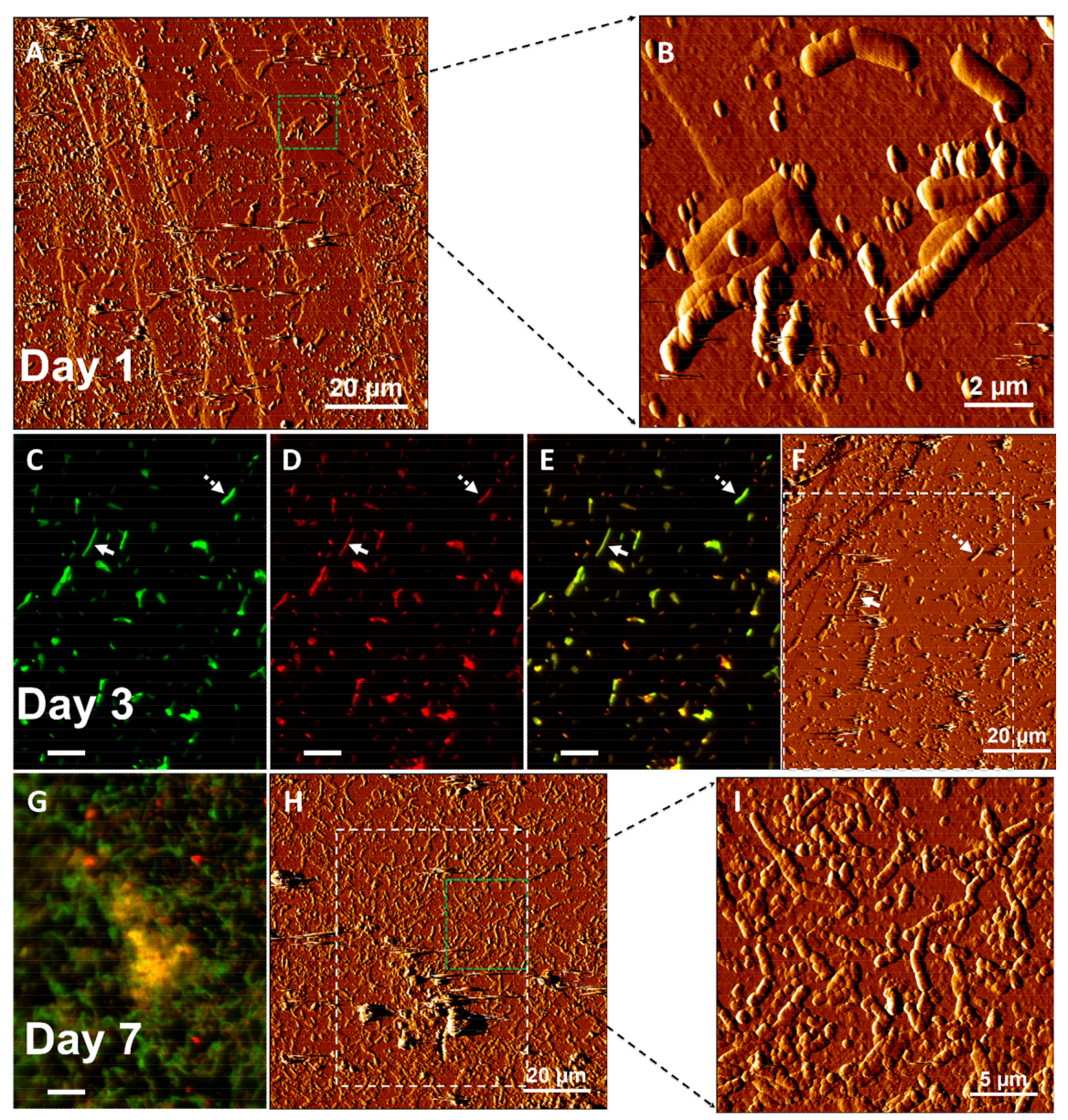

Figure 2. Surface colonization and partial biofilm formation by cells of At. ferrooxidans 61 on a pyrite coupon after 1 day (A,B), 3 days $(\mathbf{C}-\mathbf{F})$ and 7 days (G-I) of incubation at $30{ }^{\circ} \mathrm{C}$ and shaking at $130 \mathrm{rpm}$ in the dark. AFM images (A,B,F,H,I), EFM images (C-E,G). EFM images: (C) biofilm cells stained by Syto ${ }^{\circledR} 9$ (Green). (D) biofilm cells stained with Tetramethylrhodamine (TRITC)-Con A (Red). $(\mathrm{E}, \mathrm{G})$ combination of Syto ${ }^{\circledR} 9$ and TRITC-Con A. The framed area in $(\mathbf{F})$ corresponds to the same area in (C-E) observed by EFM. The framed area in (H) corresponds to the same area in (G) observed by EFM. The framed areas by green lines in $(\mathbf{A})$ and $(\mathbf{H})$ are zoomed in $(\mathrm{B})$ and $(\mathrm{I})$ respectively. Bars in $(\mathbf{C}-\mathbf{E}, \mathrm{G})$ represent $10 \mu \mathrm{m}$. Dashed and solid arrows in $(\mathbf{C}-\mathbf{F})$ point at the same bacterium, respectively. 


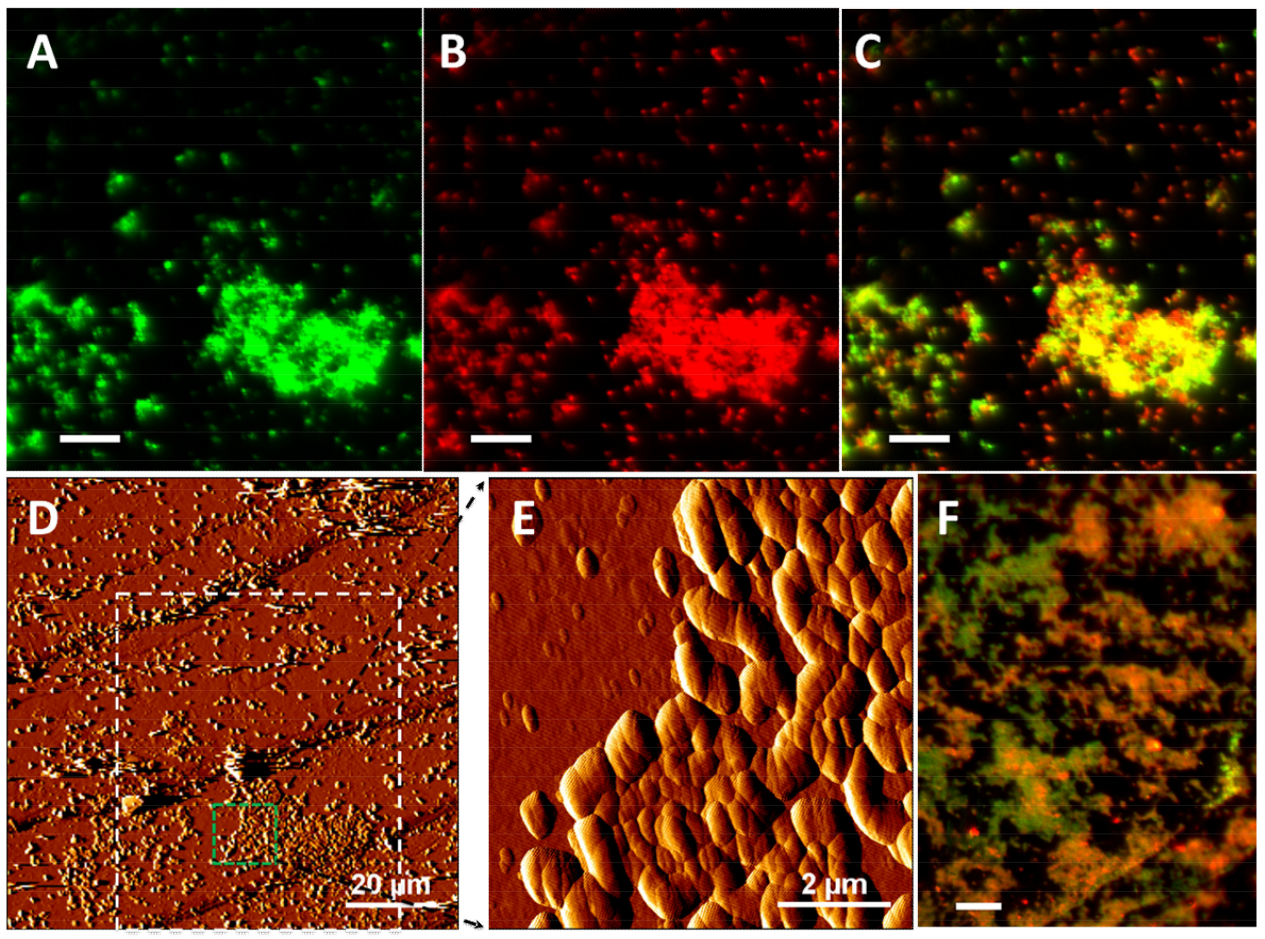

Figure 3. Surface colonization and partial biofilm formation by L. ferrooxidans ZC on a pyrite coupon after 3 days (A-E) and 7 days (F) of incubation at $30^{\circ} \mathrm{C}$ and shaking at $130 \mathrm{rpm}$ in the dark. AFM images (D,E), EFM images (A-C,F). EFM images: (A) biofilm cells stained by Syto ${ }^{\circledR} 9$ (Green). (B) biofilm cells stained by TRITC-Con A (Red). (C,F) combination of Syto ${ }^{\circledR} 9$ and TRITC-Con A. The framed area in (D) corresponds to the same area in (A-C) observed by EFM. The framed area in (D) is zoomed in (E). Typical morphology of spiral is shown in (E). Bars in (A-C,F) represent $10 \mu \mathrm{m}$.

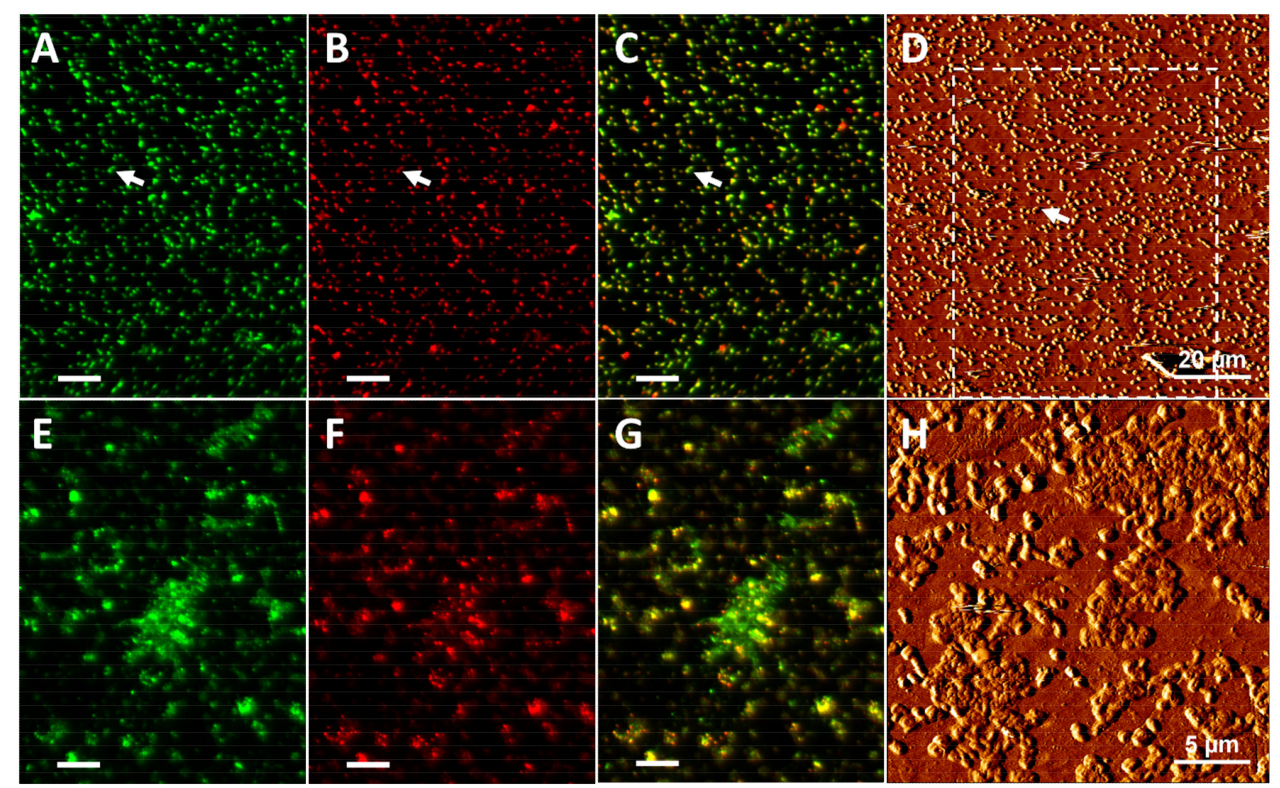

Figure 4. Surface colonization and partial biofilm formation by $S b$. thermosulfidooxidans 6 on a pyrite coupon after 3 days (A-D) and 7 days $(\mathbf{E}-\mathbf{H})$ of incubation at $30^{\circ} \mathrm{C}$ and shaking at $130 \mathrm{rpm}$ in the dark. AFM images (D,H), EFM images (A-C,E-G). EFM images: (A,E) biofilm cells stained by Syto ${ }^{\circledR} 9$ (Green). (B,F), biofilm cells stained by TRITC-Con A (Red). (C,G) combination of Syto ${ }^{\circledR} 9$ and TRITC-Con A. The framed area in (D) corresponds to the same area in (A-C) observed by EFM. Bars in (A-C,E-G) represent $10 \mu \mathrm{m}$. Solid arrows in (A-D) point at the same bacterium. 
Surface colonization by the three strains increased over time as indicated by the coverage (Table 3). Obviously, L. ferrooxidans ZC and At. ferrooxidans 61 are better colonizing pyrite surfaces than $S b$. thermosulfidooxidans 6 . This observation is consistent with previous reports $[22,23,51]$.

Table 3. Pyrite surface coverage by biofilm cells of At. ferrooxidans 61, L. ferrooxidans ZC or Sb. thermosulfidooxidans 6 determined by ImageJ (v1.52g) *.

\begin{tabular}{ccc}
\hline \multirow{2}{*}{ Strains } & \multicolumn{2}{c}{ Surface Coverage (\%) } \\
\cline { 2 - 3 } & Day 3 & Day 7 \\
\hline At. ferrooxidans 61 & $5 \pm 1$ & $32 \pm 0.5$ \\
L. ferrooxidans ZC & $10 \pm 6$ & $33 \pm 1$ \\
Sb. thermosulfidooxidans 6 & $7 \pm 1$ & $12 \pm 2$
\end{tabular}

* For coverage calculation, at least three spots (approximately $100 \times 100 \mu \mathrm{m}$ ) from each pyrite coupon were visualized under EFM. Mean values \pm standard deviations are given.

\subsection{EPS Analysis}

As part of the cell membrane of Gram-negative bacteria, KDO can be used as a marker for contamination by membrane compounds due to cell lysis during EPS extraction. The amounts of KDO in the cell pellets after cell lysis with sodium dodecyl sulfate were compared with that in EPS. KDO in the EPS fraction was detected below $<5 \%$ of that in cell pellets (not shown). A low content of KDO indicates that there was no significant cell lysis causing intracellular materials to be released into the solution during the extraction.

The EPS production of ferrous iron-grown as well as pyrite-grown cells of At. ferrooxidans 61, At. ferrooxidans 13Zn, L. ferrooxidans ZC, L. ferriphilum CC, and Sb. thermosulfidooxidans 6 were studied comparatively. As shown in Tables 4 and 5, the total EPS (colloidal EPS plus capsular EPS) amounted to $49 \mu \mathrm{g} / \mathrm{L}, 34 \mu \mathrm{g} / \mathrm{L}, 37 \mu \mathrm{g} / \mathrm{L}, 49 \mu \mathrm{g} / \mathrm{L}, 28 \mu \mathrm{g} / \mathrm{L}$ for cells grown on ferrous iron, respectively. In regards to the total EPS of cells grown on ferrous iron, the EPS amount decreased in the following order: L. ferriphilum $\mathrm{CC} \geq$ At. ferrooxidans $61>$ L. ferrooxidans $\mathrm{ZC}>$ At. ferrooxidans $13 \mathrm{Zn}>\mathrm{Sb}$. thermosulfidooxidans 6 . In contrast, pyrite-grown cells produced $2008 \mu \mathrm{g} / \mathrm{L}, 1877 \mu \mathrm{g} / \mathrm{L}$, $2261 \mu \mathrm{g} / \mathrm{L}, 4237 \mu \mathrm{g} / \mathrm{L}$, and $1812 \mu \mathrm{g} / \mathrm{L}$ EPS, respectively. Obviously, cells produce much higher amounts of EPS if grown on pyrite compared to the ones grown on ferrous iron. This is in agreement with previous studies indicating that microorganisms produce increased amounts of EPS if grown on a solid substrate compared to a soluble one [22,45]. In addition, EPS production seems to be positively correlated with surface colonization and biofilm formation (Tables 3 and 5). If grown on ferrous iron, the bacteria produce higher amounts of colloidal EPS than of capsular EPS, with the exception of cells of Sb. thermosulfidooxidans 6. In contrast, cells produce higher amounts of capsular EPS than of colloidal EPS, except strain L. ferriphilum CC, if grown on pyrite (Tables 4 and 5). Data shows that the amount of carbohydrates in the capsular EPS produced by all bacteria grown on ferrous iron is considerably higher than that in the colloidal EPS. However, the colloidal EPS contain more protein in comparison with capsular EPS (Table 4). In case of pyrite as substrate, the amount of protein is generally higher than the value for carbohydrates for both capsular and colloidal EPS. Significant amounts of uronic acids were observed in the EPS produced of cells of L. ferrooxidans ZC grown on ferrous iron, of cells of At. ferooxidans 61 grown on pyrite, and of cells of L. ferriphilum CC grown on both ferrous iron and pyrite (Tables 4 and 5). If grown on pyrite, uronic acids were detected in the colloidal EPS of cells of Sb. thermosulfidooxidans 6. In the EPS of the other strains, uronic acids were not observed or below the detection limit. It should be noted that lipids are present in most of the EPS samples but the content could not be quantified due to analytical problems.

It is known that some microorganisms excrete organic compounds to form a conditioning film on solid surfaces. This film is able to modify the solid surface properties and, thus, change the subsequent adhesion and biofilm formation [52,53]. Minerals like pyrite or chalcopyrite are more hydrophobic compared with bacterial surfaces [54,55]. During the bioleaching process, due to an 
adsorption of (macro) molecules to the mineral surfaces, a conditioning film was formed, changing the surface properties of pyrite [56]. This phenomenon has been shown also for the bioleaching archaea e.g., Sulfolobus metallicus, Acidianus sp., or Ferroplasma acidiphilum [36]. In this context, a substantial amount of EPS excreted into the solution which may have been detected as colloidal EPS, and in this way, may function to form a conditioning film actively modifying the pyrite surface.

Table 4. EPS composition $(\mu \mathrm{g} / \mathrm{L})$ of the bacteria grown on ferrous iron.

\begin{tabular}{|c|c|c|c|c|c|c|}
\hline \multirow{2}{*}{\multicolumn{2}{|c|}{ EPS Composition }} & \multicolumn{5}{|c|}{ Strains } \\
\hline & & $\begin{array}{l}\text { At. ferrooxidans } \\
61\end{array}$ & $\begin{array}{l}\text { At. ferrooxidans } \\
\text { 13Zn }\end{array}$ & $\begin{array}{l}\text { L. ferrooxidans } \\
\text { ZC }\end{array}$ & $\begin{array}{l}\text { L. ferriphilum } \\
\text { CC }\end{array}$ & $\begin{array}{c}\text { Sb. thermosulfidooxidans } \\
6\end{array}$ \\
\hline \multirow{3}{*}{ Colloidal } & Protein & 26 & 16 & 15 & 22 & 10 \\
\hline & Carbohydrates & 5 & 5 & 4 & 3 & 3 \\
\hline & Uronic acid & BDL & $\mathrm{BDL}$ & 1 & 2 & BDL \\
\hline \multirow{3}{*}{ Capsular } & Protein & 12 & 8 & 11 & 15 & 11 \\
\hline & Carbohydrates & 6 & 5 & 5 & 6 & 4 \\
\hline & Uronic acid & BDL & BDL & 1 & 1 & BDL \\
\hline
\end{tabular}

BDL: below detection limit.

Table 5. EPS composition ( $\mu \mathrm{g} / \mathrm{L})$ of bacteria grown on pyrite.

\begin{tabular}{|c|c|c|c|c|c|c|}
\hline \multirow{2}{*}{\multicolumn{2}{|c|}{ EPS Composition }} & \multicolumn{5}{|c|}{ Strains } \\
\hline & & $\begin{array}{l}\text { At. ferrooxidans } \\
61\end{array}$ & $\begin{array}{l}\text { At. ferrooxidans } \\
\text { 13Zn }\end{array}$ & $\begin{array}{l}\text { L. ferrooxidans } \\
\text { ZC }\end{array}$ & $\begin{array}{l}\text { L. ferriphilum } \\
\text { CC }\end{array}$ & $\begin{array}{c}\text { Sb. thermosulfidooxidans } \\
6\end{array}$ \\
\hline \multirow{3}{*}{ Colloidal } & Protein & 468 & 591 & 568 & 1023 & 468 \\
\hline & Carbohydrates & 408 & 286 & 475 & 1576 & 181 \\
\hline & Uronic acid & 31 & $\mathrm{BDL}$ & BDL & 73 & 60 \\
\hline \multirow{3}{*}{ Capsular } & Protein & 750 & 659 & 772 & 761 & 704 \\
\hline & Carbohydrates & 307 & 341 & 446 & 744 & 399 \\
\hline & Uronic acid & 44 & BDL & BDL & 60 & BDL \\
\hline
\end{tabular}

BDL: below detection limit.

The chemical composition of the EPS varies with their substrate consequently, and also the attachment differs as a function of substrate [21]. EPS produced by At. ferrooxidans mainly consist of natural sugars and lipids [22,45]. For cells of L. ferrooxidans ${ }^{\mathrm{T}}$, the total amount of EPS increases and EPS composition changes with the increased concentrations of galactose and ferrous iron. In addition, cells pre-cultured on galactose produce "stickier" EPS than the ones on ferrous iron [57]. Cells of $S b$. thermosulfidooxidans excrete a substantial amount of humic acids apart from proteins and carbohydrates [56]. The EPS of other leaching relevant bacteria like Acidiphilum 3.2Sup(5) mainly contain carbohydrates and proteins. However, an improved EPS extraction as well as a reduced degree of cell lysis were obtained by using EDTA in comparison with other methods like $\mathrm{NaOH}$, ion exchange resin, and heating and centrifugation [58]. EPS from a mixed culture dominated by At. caldus and L. ferriphilum grown on a chalcopyrite concentrate contained proteins, lipids, carbohydrates and iron(III)-ions [59]. A study on the EPS composition was done for mixed cultures of mesophiles, moderate thermophiles, and thermophiles growing on various mineral resources such as pyrite, sphalerite, and chalcopyrite in continuously operated bioleaching systems. Seventy percent of the EPS was mainly carbohydrates plus a smaller amount of proteins and trace levels of humic and uronic acids [60]. The characterization of two acidophilic microbial biofilms in the Iron Mountain, California, USA, indicated that EPS constituted of carbohydrates, metals, proteins and minor quantities of DNA and lipids [61]. The majority of research on the nature of the EPS produced by acidophiles like At. ferrooxidans was done in studies involving pyrite, sulfur and ferrous sulfate as substrates. These studies investigated the EPS as a whole and did not distinguish between the capsular and colloidal fractions. We detected that acidophiles excrete a substantial amount of EPS into the solution, even if grown on ferrous iron (Tables 4 and 5). The reason(s) for this and the function of colloidal EPS need further studies. 


\section{Conclusions}

Several isolates from biotopes of sulfide ores in Armenia show the capability to form biofilms and produce EPS, while grown on either soluble ferrous iron or solid pyrite surfaces. The dissolution of pyrite is correlated with the quantity of adhering/attached cells. A monolayer biofilm developed on pyrite by At. ferrooxidans 61, Sb. thermosulfidooxidans 6 and L. ferrooxidans ZC. Large cell clusters formed by L. ferrooxidans ZC indicate their ability to produce high amount of EPS on pyrite. Biochemical analyses of EPS of the planktonic and attached cells on pyrite grains show that the main components of EPS are proteins, carbohydrates and uronic acids.

Supplementary Materials: The following are available online at http://www.mdpi.com/2075-163X/9/2/69/s1, Figure S1: Sampling areas in different biotopes of sulfide ores in Armenia.

Author Contributions: A.V. and R.Z. conceived and designed the experiments; A.V., A.K., and R.Z. performed the experiments; A.V. and N.V. analyzed the data; N.V. and W.S. contributed reagents/materials/analysis tools; A.V. and R.Z. wrote the manuscript. WS corrected the manuscript.

Funding: This work was supported by the MES-BMBF STC Grant 12GE 005 of the Ministry of Education and Science of Armenia and the German Federal Ministry of Education and Research.

Conflicts of Interest: The authors declare no conflict of interest. The funders had no role in the design of the study; in the collection, analyses, or interpretation of data; in the writing of the manuscript, and in the decision to publish the results.

\section{References}

1. Dew, D.W.; Lawson, E.N.; Broadhurst, J.L. The biox ${ }^{\circledR}$ process for biooxidation of gold-bearing ores or concentrates. In Biomining; Springer: Berlin/Heidelberg, Germany, 1997; pp. 45-80.

2. Johnson, D.B. The Evolution, current status, and future prospects of using biotechnologies in the mineral extraction and metal recovery sectors. Minerals 2018, 8, 343. [CrossRef]

3. Kaksonen, A.H.; Boxall, N.J.; Gumulya, Y.; Khaleque, H.N.; Morris, C.; Bohu, T.; Cheng, K.Y.; Usher, K.M.; Lakaniemi, A.-M. Recent progress in biohydrometallurgy and microbial characterisation. Hydrometallurgy 2018, 180, 7-25. [CrossRef]

4. Schippers, A.; Hedrich, S.; Vasters, J.; Drobe, M.; Sand, W.; Willscher, S. Biomining: Metal recovery from ores with microorganisms. In Geobiotechnology I: Metal-Related Issues; Schippers, A., Glombitza, F., Sand, W., Eds.; Springer: Berlin/Heidelberg, Germany, 2014; pp. 1-47.

5. Coram, N.J.; Rawlings, D.E. Molecular relationship between two groups of the genus Leptospirillum and the finding that Leptospirillum ferriphilum sp. Nov. Dominates South African commercial biooxidation tanks that operate at $40^{\circ} \mathrm{C}$. Appl. Environ. Microbiol. 2002, 68, 838-845. [CrossRef] [PubMed]

6. Lawson, E. The composition of mixed populations of leaching bacteria active in gold and nickel recovery from sulphide ores. In Proceedings of the International Biohydrometallurgy Symposium, IBS97, Sydney, Australia, 4-6 August 1997; Australian Mineral Foundation: Glenside, South Australia, 1997; p. 4.

7. Rawlings, D.; Coram, N.; Gardner, M.; Deane, S. Thiobacillus caldus and Leptospirillum ferrooxidans are widely distributed in continuous flow biooxidation tanks used to treat a variety of metal containing ores and concentrates. In Process Metallurgy; Elsevier: New York, NY, USA, 1999; Volume 9, pp. 777-786.

8. Schippers, A. Microorganisms involved in bioleaching and nucleic acid-based molecular methods for their identification and quantification. In Microbial Processing of Metal Sulfides; Donati, E., Sand, W., Eds.; Springer: Dordrecht, The Netherlands, 2007; pp. 3-33.

9. Foucher, S.; Battaglia-Brunet, F.; d'Hugues, P.; Clarens, M.; Godon, J.; Morin, D. Evolution of the bacterial population during the batch bioleaching of a cobaltiferous pyrite in a suspended-solids bubble column and comparison with a mechanically agitated reactor. Hydrometallurgy 2003, 71, 5-12. [CrossRef]

10. Goltsman, D.S.A.; Denef, V.J.; Singer, S.W.; VerBerkmoes, N.C.; Lefsrud, M.; Mueller, R.S.; Dick, G.J.; Sun, C.L.; Wheeler, K.E.; Zemla, A. Community genomic and proteomic analyses of chemoautotrophic iron-oxidizing "Leptospirillum rubarum" (Group II) and "Leptospirillum ferrodiazotrophum" (Group III) bacteria in acid mine drainage biofilms. Appl. Environ. Microbiol. 2009, 75, 4599-4615. [CrossRef] [PubMed]

11. Markosyan, G. A new iron-oxidizing bacterium, Leptospirillum ferrooxidans gen. Et sp. Nov. Biol. Zh. Arm. $1972,25,26$. 
12. Vardanyan, N.; Akopyan, V. Leptospirillum-like bacteria and evaluation of their role in pyrite oxidation. Microbiology 2003, 72, 438-442. [CrossRef]

13. Sand, W.; Rohde, K.; Sobotke, B.; Zenneck, C. Evaluation of Leptospirillum ferrooxidans for leaching. Appl. Environ. Microbiol. 1992, 58, 85-92.

14. Fu, B.; Zhou, H.; Zhang, R.; Qiu, G. Bioleaching of chalcopyrite by pure and mixed cultures of Acidithiobacillus spp. and Leptospirillum ferriphilum. Int. Biodeterior. Biodegrad. 2008, 62, 109-115. [CrossRef]

15. Okibe, N.; Gericke, M.; Hallberg, K.B.; Johnson, D.B. Enumeration and characterization of acidophilic microorganisms isolated from a pilot plant stirred-tank bioleaching operation. Appl. Environ. Microbiol. 2003, 69, 1936-1943. [CrossRef]

16. Vera, M.; Schippers, A.; Sand, W. Progress in bioleaching: Fundamentals and mechanisms of bacterial metal sulfide oxidation-part A. Appl. Microbiol. Biotechnol. 2013, 97, 7529-7541. [PubMed]

17. Sand, W.; Gehrke, T.; Jozsa, P.G.; Schippers, A. (bio)chemistry of bacterial leaching-Direct vs. Indirect bioleaching. Hydrometallurgy 2001, 59, 159-175. [CrossRef]

18. Sand, W.; Gerke, T.; Hallmann, R.; Schippers, A. Sulfur chemistry, biofilm, and the (in)direct attack mechanism-A critical evaluation of bacterial leaching. Appl. Microbiol. Biotechnol. 1995, 43, 961-966. [CrossRef]

19. Li, Q.; Wang, Q.; Zhu, J.; Zhou, S.; Gan, M.; Jiang, H.; Sand, W. Effect of extracellular polymeric substances on surface properties and attachment behavior of Acidithiobacillus ferrooxidans. Minerals 2016, 6, 100. [CrossRef]

20. Li, Q.; Sand, W.; Zhang, R. Enhancement of biofilm formation on pyrite by Sulfobacillus thermosulfidooxidans. Minerals 2016, 6, 71. [CrossRef]

21. Zhang, R.; Bellenberg, S.; Neu, T.R.; Sand, W.; Vera, M. The biofilm lifestyle of acidophilic metal/sulfur-oxidizing microorganisms. In Biotechnology of Extremophiles: Advances and Challenges; Rampelotto, P.H., Ed.; Springer: Basel, Switzerland, 2016; pp. 177-213.

22. Harneit, K.; Göksel, A.; Kock, D.; Klock, J.-H.; Gehrke, T.; Sand, W. Adhesion to metal sulfide surfaces by cells of Acidithiobacillus ferrooxidans, Acidithiobacillus thiooxidans and Leptospirillum ferrooxidans. Hydrometallurgy 2006, 83, 245-254. [CrossRef]

23. Li, Q.; Yang, B.; Zhu, J.; Jiang, H.; Li, J.; Zhang, R.; Sand, W. Comparative analysis of attachment to chalcopyrite of three mesophilic iron and/or sulfur-oxidizing acidophiles. Minerals 2018, 8, 406. [CrossRef]

24. Flemming, H.-C.; Neu, T.R.; Wingender, J. The Perfect Slime: Microbial Extracellular Polymeric Substances (EPS); IWA Publishing: London, UK, 2016.

25. Sutherland, I.W. Biofilm exopolysaccharides: A strong and sticky framework. Microbiology 2001, 147, 3-9. [CrossRef] [PubMed]

26. Van Wolferen, M.; Orell, A.; Albers, S.V. Archaeal biofilm formation. Nat. Rev. Microbiol. 2018, 16, 699-713. [CrossRef]

27. Flemming, H.-C.; Wingender, J.; Szewzyk, U.; Steinberg, P.; Rice, S.A.; Kjelleberg, S. Biofilms: An emergent form of bacterial life. Nat. Rev. Microbiol. 2016, 14, 563-575. [CrossRef]

28. Flemming, H.C.; Neu, T.R.; Wozniak, D.J. The EPS matrix: The "house of biofilm cells". J. Bacteriol. 2007, 189, 7945-7947. [CrossRef] [PubMed]

29. Castro, L.; Zhang, R.; Muñoz, J.A.; González, F.; Blázquez, M.L.; Sand, W.; Ballester, A. Characterization of exopolymeric substances (EPS) produced by Aeromonas hydrophila under reducing conditions. Biofouling 2014, 30, 501-511. [CrossRef] [PubMed]

30. Sheng, G.-P.; Yu, H.-Q.; Li, X.-Y. Extracellular polymeric substances (EPS) of microbial aggregates in biological wastewater treatment systems: A review. Biotechnol. Adv. 2010, 28, 882-894. [CrossRef] [PubMed]

31. Sand, W.; Gehrke, T. Extracellular polymeric substances mediate bioleaching/biocorrosion via interfacial processes involving iron(III) ions and acidophilic bacteria. Res. Microbiol. 2006, 157, 49-56. [CrossRef] [PubMed]

32. Vardanyan, A.; Stepanyan, S.; Vardanyan, N.; Markosyan, L.; Sand, W.; Vera, M.; Zhang, R. Study and assessment of microbial communities in natural and commercial bioleaching systems. Miner. Eng. 2015, 81, 167-172. [CrossRef]

33. Mackintosh, M.E. Nitrogen fixation by Thiobacillus ferrooxidans. Microbiology 1978, 105, 215-218. [CrossRef]

34. Gerhardt, P.; Murray, R.; Costilow, R.; Nester, E.W.; Wood, W.A.; Krieg, N.; Phillips, G.B. Manual of Methods for General Bacteriology; American Society for Microbiology: Washington, DC, USA, 1981. 
35. Zhang, R.; Bellenberg, S.; Castro, L.; Neu, T.R.; Sand, W.; Vera, M. Colonization and biofilm formation of the extremely acidophilic archaeon Ferroplasma acidiphilum. Hydrometallurgy 2014, 150, 245-252. [CrossRef]

36. Zhang, R.Y.; Neu, T.R.; Bellenberg, S.; Kuhlicke, U.; Sand, W.; Vera, M. Use of lectins to in situ visualize glycoconjugates of extracellular polymeric substances in acidophilic archaeal biofilms. Microb. Biotechnol. 2015, 8, 448-461. [CrossRef]

37. Abramoff, M.D.; Magalhaes, P.J.; Ram, S.J. Image processing with imagej. Biophotonics Intern. 2004, 11, 36-42.

38. Bellenberg, S.; Florian, B.M.; Vera, M.A.; Rohwerder, T.; Sand, W. Comparative study of planktonic and sessile cells from pure and mixed cultures of Acidithiobacillus ferrooxidans and Acidiphilium cryptum growing on pyrite. Adv. Mater. Res. 2009, 71-73, 333-336. [CrossRef]

39. Dubois, M.; Gilles, K.A.; Hamilton, J.K.; Rebers, P.; Smith, F. Colorimetric method for determination of sugars and related substances. Anal. Chem. 1956, 28, 350-356. [CrossRef]

40. Bradford, M.M. A rapid and sensitive method for the quantitation of microgram quantities of protein utilizing the principle of protein-dye binding. Anal. Biochem. 1976, 72, 248-254. [CrossRef]

41. Blumenkrantz, N.; Asboe-Hansen, G. New method for quantitative determination of uronic acids. Anal. Biochem. 1973, 54, 484-489. [CrossRef]

42. Karkhanis, Y.D.; Zeltner, J.Y.; Jackson, J.J.; Carlo, D.J. A new and improved microassay to determine 2-keto-3-deoxyoctonate in lipopolysaccharide of gram-negative bacteria. Anal. Biochem. 1978, 85, 595-601. [CrossRef]

43. DiSpirito, A.A.; Dugan, P.R.; Tuovinen, O.H. Sorption of Thiobacillus ferrooxidans to particulate material. Biotechnol. Bioeng. 1983, 25, 1163-1168. [CrossRef] [PubMed]

44. Baldensperger, J.; Guarraia, L.; Humphreys, W. Scanning electron microscopy of thiobacilli grown on colloidal sulfur. Arch. Microbiol. 1974, 99, 323-329. [CrossRef] [PubMed]

45. Gehrke, T.; Telegdi, J.; Thierry, D.; Sand, W. Importance of extracellular polymeric substances from Thiobacillus ferrooxidans for bioleaching. Appl. Environ. Microbiol. 1998, 64, 2743-2747.

46. Sand, W.; Gehrke, T.; Hallmann, R.; Schippers, A. Towards a novel bioleaching mechanism. Miner. Process. Extr. Metall. Rev. 1998, 19, 97-106. [CrossRef]

47. Liu, J.; Li, Q.; Sand, W.; Zhang, R. Influence of Sulfobacillus thermosulfidooxidans on initial attachment and pyrite leaching by thermoacidophilic archaeon Acidianus sp. DSM 29099. Minerals 2016, 6, 76. [CrossRef]

48. Bellenberg, S.; Barthen, R.; Boretska, M.; Zhang, R.; Sand, W.; Vera, M. Manipulation of pyrite colonization and leaching by iron-oxidizing Acidithiobacillus species. Appl. Microbiol. Biotechnol. 2015, 99, 1435-1449.

49. Noël, N.; Florian, B.; Sand, W. AFM \& EFM study on attachment of acidophilic leaching organisms. Hydrometallurgy 2010, 104, 370-375.

50. Florian, B.; Noël, N.; Thyssen, C.; Felschau, I.; Sand, W. Some quantitative data on bacterial attachment to pyrite. Miner. Eng. 2011, 24, 1132-1138. [CrossRef]

51. Bellenberg, S.; Buetti-Dinh, A.; Galli, V.; Ilie, O.; Herold, M.; Christel, S.; Boretska, M.; Pivkin, I.V.; Wilmes, P.; Sand, W. Automated microscopic analysis of metal sulfide colonization by acidophilic microorganisms. Appl. Environ. Microbiol. 2018, 84, e01835-e01818. [CrossRef] [PubMed]

52. Bakker, D.P.; Busscher, H.J.; van Zanten, J.; de Vries, J.; Klijnstra, J.W.; van der Mei, H.C. Multiple linear regression analysis of bacterial deposition to polyurethane coatings after conditioning film formation in the marine environment. Microbiology 2004, 150, 1779-1784. [CrossRef] [PubMed]

53. Garg, A.; Jain, A.; Bhosle, N.B. Chemical characterization of a marine conditioning film. Int. Biodeterior. Biodegrad. 2009, 63, 7-11. [CrossRef]

54. Diao, M.; Taran, E.; Mahler, S.; Nguyen, T.A.; Nguyen, A.V. Quantifying adhesion of acidophilic bioleaching bacteria to silica and pyrite by atomic force microscopy with a bacterial probe. Colloids Surf. B Biointerfaces 2014, 115, 229-236. [CrossRef] [PubMed]

55. Zhu, J.; Li, Q.; Jiao, W.; Jiang, H.; Sand, W.; Xia, J.; Liu, X.; Qin, W.; Qiu, G.; Hu, Y. Adhesion forces between cells of Acidithiobacillus ferrooxidans, Acidithiobacillus thiooxidans or Leptospirillum ferrooxidans and chalcopyrite. Colloids Surf. B Biointerfaces 2012, 94, 95-100. [CrossRef]

56. Li, Q.; Sand, W. Mechanical and chemical studies on EPS from Sulfobacillus thermosulfidooxidans: From planktonic to biofilm cells. Colloids Surf. B Biointerfaces 2017, 153, 34-40. [CrossRef]

57. Aguirre, P.; Guerrero, K.; Sanchez-Rodriguez, A.; Gentina, J.C.; Schippers, A. Making sticky cells: Effect of galactose and ferrous iron on the attachment of Leptospirillum ferrooxidans to mineral surfaces. Res. Microbiol. 2018, 169, 569-575. [CrossRef] 
58. Tapia, J.; Munoz, J.; Gonzalez, F.; Blázquez, M.; Malki, M.; Ballester, A. Extraction of extracellular polymeric substances from the acidophilic bacterium Acidiphilium 3.2 sup (5). Water Sci. Technol. 2009, 59, 1959-1967. [CrossRef]

59. Zeng, W.; Qiu, G.; Zhou, H.; Liu, X.; Chen, M.; Chao, W.; Zhang, C.; Peng, J. Characterization of extracellular polymeric substances extracted during the bioleaching of chalcopyrite concentrate. Hydrometallurgy 2010, 100, 177-180. [CrossRef]

60. Govender, Y.; Gericke, M. Extracellular polymeric substances (EPS) from bioleaching systems and its application in bioflotation. Miner. Eng. 2011, 24, 1122-1127. [CrossRef]

61. Jiao, Y.; Cody, G.D.; Harding, A.K.; Wilmes, P.; Schrenk, M.; Wheeler, K.E.; Banfield, J.F.; Thelen, M.P. Characterization of extracellular polymeric substances from acidophilic microbial biofilms. Appl. Environ. Microbiol. 2010, 76, 2916-2922. [CrossRef] [PubMed]

(C) 2019 by the authors. Licensee MDPI, Basel, Switzerland. This article is an open access article distributed under the terms and conditions of the Creative Commons Attribution (CC BY) license (http://creativecommons.org/licenses/by/4.0/). 